\title{
Clinical impact of MMP and TIMP gene polymorphisms in gastric
}

\section{cancer}

\author{
FJGM Kubben', CFM Sier', MJW Meijer', M van den Berg', JJ van der Reijden', G Griffioen', CJH van de Velde', \\ CBHW Lamers' and HW Verspaget ${ }^{*}, 1$
}

'Department of Gastroenterology and Hepatology, Leiden University Medical Center, Leiden, The Netherlands; ${ }^{2}$ Department of Oncologic Surgery, Leiden University Medical Center, Leiden, The Netherlands

Gastric cancers express enhanced levels of matrix metalloproteinases (MMPs) and their tissue inhibitors (TIMPs). Single-nucleotide polymorphisms (SNPs) in MMP and TIMP genes may be associated with disease susceptibility and might also affect their antigen expression. We studied the genotype distribution and allele frequencies of SNPs of MMP-2, - 7, -8 and -9 and TIMP-I and -2 in gastric cancer patients in relation to tumour progression, patient survival and tissue antigen expression. The genotype distribution and allele frequencies were similar in gastric cancer patients and controls, except for MMP-7_|8|A>G. In addition, the genotype distribution of MMP-7_-18|A>G was associated with Helicobacter pylori status $\left(\chi^{2} 7.8, P=0.005\right)$ and tumour-related survival of the patients. Single-nucleotide polymorphism TIMP-2303C>T correlated significantly with the WHO classification $\left(\chi^{2} 5.9, P=0.03\right)$ and also strongly with tumour-related survival (log rank II.74, $P=0.0006$ ). Single-nucleotide polymorphisms of MMP-2, -8, -9 and TIMP-I were not associated with tumour-related survival. Only the gene promoter MMP-2 $1306 \mathrm{C}>$ T polymorphism correlated significantly with the protein level within the tumours. First-order dendrogram cluster analysis combined with Cox analysis identified the MMP-7_-18|A>G and TIMP-2 $303 \mathrm{C}>\mathrm{T}$ polymorphism combination to have a major impact on patients survival outcome. We conclude that MMP-related SNPs, especially MMP-7_-18|A>G and TIMP-2 $303 \mathrm{C}>\mathrm{T}$, may be helpful in identifying gastric cancer patients with a poor clinical outcome.

British Journal of Cancer (2006) 95, 744-75I. doi:I0.1038/sj.bjc.6603307 www.bjcancer.com

Published online 29 August 2006

(c) 2006 Cancer Research UK

Keywords: survival; Borrmann; Laurén; Helicobacter pylori; protein level

In the process of tumour dissemination and metastasis, matrix metalloproteinases (MMPs) and their tissue inhibitors (TIMPs) play an important role in the invasion of tissue, vascular and lymphatic basal membranes and the subsequent coordinated proteolytic breakdown and reconstitution of extracellular matrix (Kohn and Liotta, 1995). Matrix metalloproteinases also modulate cell proliferation, apoptosis and host immune surveillance (Egeblad and Werb, 2002). Immunohistochemical and in situ hybridisation studies as well as quantitative assays have demonstrated that gastric carcinomas contain enhanced amounts of MMPs (Nomura et al, 1995; Honda et al, 1996; Mori et al, 1997). We previously reported significantly enhanced MMP and TIMP levels in gastric carcinomas, but only MMP-2 was independently associated with a poor overall survival of the patients (Kubben et al, 2006). Single-nucleotide polymorphisms (SNPs) within MMP genes are thought to influence the expression of MMPs and/or even seem to be associated with the susceptibility for the development of malignancy. For instance, a functional SNP in the MMP-2 gene promoter $(-1306 \mathrm{C}>\mathrm{T})$ was found to be associated with the risk of the development, but not the metastatic behaviour of gastric cardia adenocarcinoma, in an ethnic

*Correspondence: Dr HW Verspaget; E-mail: H.W.Verspaget@lumc.nl Received 20 April 2006; revised 6 July 2006; accepted 12 July 2006; published online 29 August 2006
Chinese population (Miao et al, 2003). Furthermore, the frequency of a functional SNP of MMP-7 $(-181 \mathrm{~A}>\mathrm{G})$ was found to be significantly higher in gastric cardiac carcinoma patients compared to controls in another Chinese study (Zhang et al, 2005). Particularly, genotypes with the MMP-7 ${ }_{-181 G}$ allele $(A / G+G / G)$ showed a significantly increased susceptibility for gastric cardiac carcinoma with an odds ratio of 1.96 (Zhang et al, 2005). Finally, a significant association in Japanese gastric cancer patients was found between an SNP in the promoter of the MMP-9 gene $(-1562 \mathrm{C}>\mathrm{T})$ and the degree of tumour invasion, clinical stage and lymphatic invasion (Matsumura et al, 2005). However, as indicated above, these studies on MMP-SNPs in gastric carcinoma patients describe ethnic Chinese and Japanese populations with a known high incidence of gastric cancer.

In the present study, we determined the genotype distribution and allele frequencies of SNPs of MMP-2, -7, -8 and -9 , and of TIMP-1 and -2 in a cohort of 79 Caucasian gastric carcinoma patients, in which we previously assessed clinical relevance of the respective protein levels. In order to get insight into the functional and clinical contribution of these MMP-related gene polymorphisms, we assessed the relation between the distribution of these SNPs and the respective protein levels in tumour and adjacent normal tissue as well as the relation of the SNPs with established clinico-pathological parameters and the relation of the gene polymorphisms with tumour-related survival. 


\section{MATERIALS AND METHODS}

\section{Patients and study design}

Fresh histologically normal tissue specimens of 79 patients (21 females and 58 males, mean age 66 years, range $35-91$ years) who underwent resection for primary gastric adenocarcinoma at the department of Oncologic Surgery of the Leiden University Medical Center were collected prospectively, as described before (Janssen et al, 2002). Various clinico-pathological data were (re-)evaluated or collected from patient files by one gastroenterologist and one pathologist (Janssen et al, 2002). All carcinomas were classified according to the TNM classification (Hermanek and Sobin, 1992) and localisation as well as diameters of the tumours were registered. Microscopical histological parameters, including differentiation-grade, classification according to WHO, Borrmann and Laurén, as well as the presence of Helicobacter pylori $(H p)$ and intestinal metaplasia in the normal gastric mucosa were assessed. All patients entered the study at operation date and a patient's time experience ended in the event of death or, when still alive, at the common closing date. The minimal follow-up was 33 months with a decreasing overall survival according to TNM stage, that is, from TNM I $(n=23)$, to TNM II $(n=24)$, to TNM III $(n=25)$, and to TNM IV $(n=7)$. Genomic DNA was isolated using the salting out method (Miller et al, 1988). In addition, DNA was extracted from peripheral blood leucocytes of 169 healthy volunteers (38\% male, median age 33 years (range 18-73 years), $>95 \%$ Caucasian) as described before (van der Veek et al, 2005).

\section{Single-nucleotide polymorphism analyses}

Genotypes were analysed by PCR-based techniques as described in Table 1.

\section{Antigen determination and protein concentration}

From 50-100 mg of wet tissue samples, homogenates were prepared. The samples were wet weighted, and $1 \mathrm{ml}$ of $0.1 \mathrm{M}$ Tris-HCl (pH 7.5) with $0.1 \%\left({\mathrm{v} . \mathrm{v}^{-1}}^{-1}\right)$ Tween-80 extraction buffer per $60 \mathrm{mg}$ sample was added as described previously. The protein concentration was determined using the method of Lowry et al (1951). Specific ELISAs for the MMP and TIMP antigen determination were performed as recently described (Kubben et al, 2006).

\section{Statistical analysis}

Statistical analyses were performed using SPSS11.0 Statistical Package (2004, SPSS Inc., Chicago, IL, USA). Hardy-Weinberg analysis was performed using the chi-square $\left(\chi^{2}\right)$ or Fisher's exact test to examine differences in the distribution of alleles and genotypes between patients and controls. Odds ratios and confidence intervals $(95 \%)$ were calculated by logistic regression. For the tumour-related survival analysis, the clinico-pathological parameters were dichotomised as described before (Sier et al, 1996). Univariate survival analyses were performed with the Cox proportional hazards model, using the clinicopathological parameters and MMP-SNPs, resulting in the identification of covariates that significantly correlated with the survival of the patients. Multivariate survival analysis was performed by separately adding the MMP-SNPs variables to all the dichotomised clinico-pathological parameters. Tumourrelated survival curves were constructed using the method of Kaplan and Meier including the log rank test. Group means for antigen levels were compared using two-tailed MannWhitney $U$-tests. Differences were considered significant when $P \leqslant 0.05$.

Table I Primer sequences and PCR conditions for amplification of MMP and TIMP SNPs

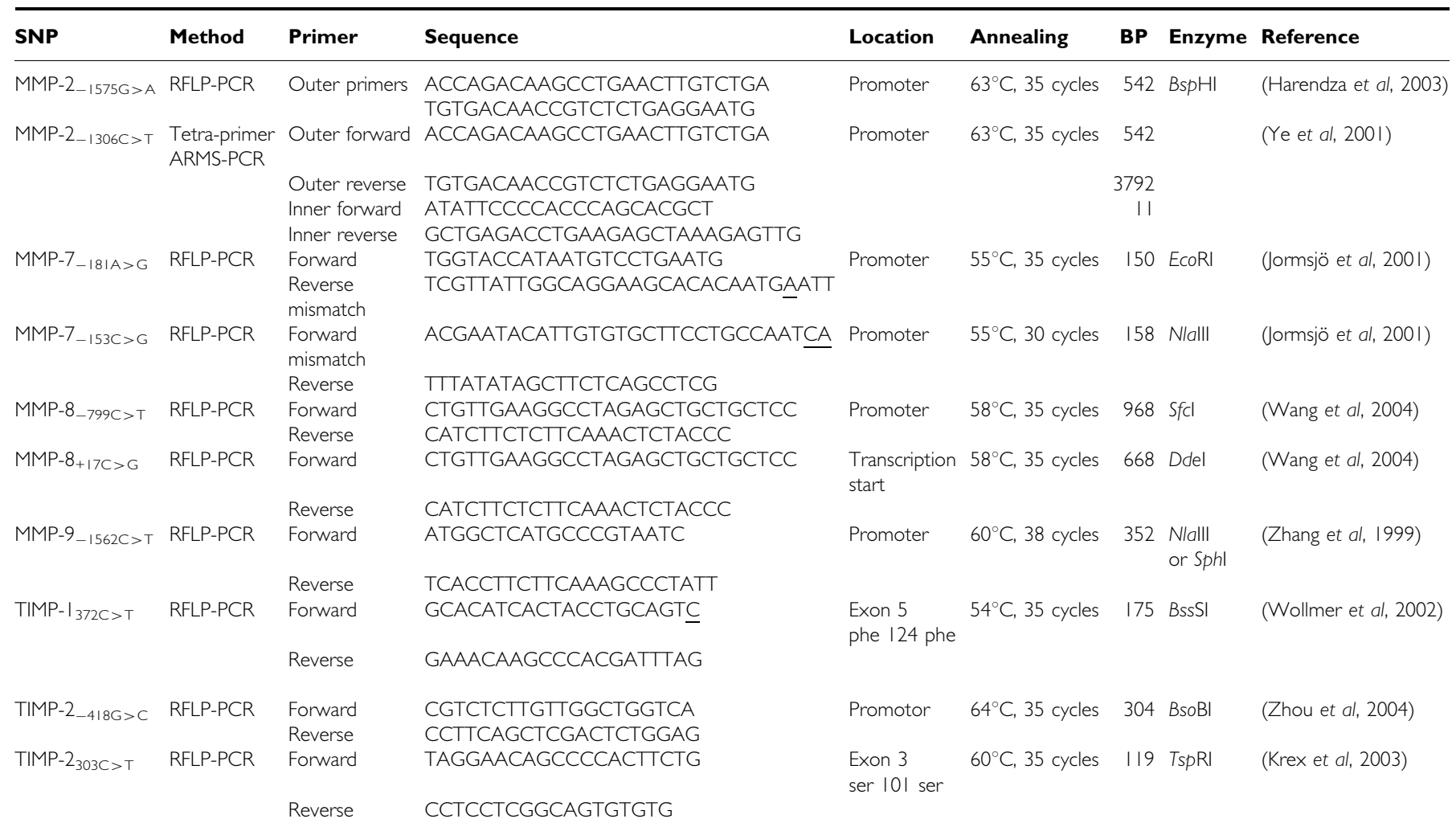

ARMS = amplification refractory mutation system; $M M P=$ matrix metalloproteinase; $P C R=$ polymerase chain reaction; $R F L P=$ restriction fragment length polymorphism; $\mathrm{SNP}=$ single-nucleotide polymorphism; TIMP = tissue inhibitor of metalloproteinase. Deliberate mismatches in primers are underlined. 


\section{RESULTS}

The genotype distribution and allele frequencies of the SNPs for MMP-2, -7, -8, -9, TIMP-1 and -2 for the 79 gastric cancer patients and 169 control subjects are summarised in Table 2. Singlenucleotide polymorphisms $-1306 \mathrm{C}>\mathrm{T}$ and $-1575 \mathrm{G}>\mathrm{A}$ for MMP-2 were found to be in complete linkage disequilibrium and consequently, in the rest of the study only MMP- $2_{-1306 \mathrm{C}>\mathrm{T}}$ will be described. None of the genotype distributions in the control group or in the cancer patients deviated from the Hardy-Weinberg equilibrium (data not shown). Matrix metalloproteinase-7 $-181 \mathrm{~A}>\mathrm{G}$ was the only polymorphism differently distributed among gastric carcinoma patients compared with control subjects: AA 43.0\%, AG $46.8 \%$, and GG $10.1 \%$ in patients $v$ s AA $27.2 \%$, AG $62.7 \%$ and GG $10.1 \%$ in controls $(P<0.04$; Table 2$)$. Comparison of the genotype distribution of our Caucasian control subjects with those published on other mainly Asiatic control groups (Wollmer et al, 2002; Ghilardi et al, 2003; Krex et al, 2003; Miao et al, 2003; Wang et al, 2004; Zhou et al, 2004; Matsumura et al, 2005; Zhang et al, 2005) showed significant differences for MMP- $2_{-1306 \mathrm{C}>\mathrm{T}}$, MMP$7_{-181 \mathrm{~A}>\mathrm{G}}$, TIMP-1 $372 \mathrm{C}>\mathrm{T}$ and TIMP-2 $-418 \mathrm{G}>\mathrm{C}$ (Table 3).

All the SNPs were evaluated for association with the clinicopathological parameters. Correlations were found for MMP$2_{-1306 \mathrm{C}>\mathrm{T}}$ with Borrmann's classification (fungating $v s$ infiltrating:

Table 2 Allele frequencies and genotype distribution of MMP and TIMP SNPs in gastric carcinoma patients $(n=79)$ and controls $(n=169)$

\begin{tabular}{|c|c|c|c|c|c|c|c|c|c|c|c|c|c|c|c|c|c|c|c|c|c|c|c|}
\hline \multirow[b]{2}{*}{ SNP } & & \multicolumn{9}{|c|}{ Patients } & \multicolumn{9}{|c|}{ Controls } & \multirow[b]{2}{*}{$\chi^{2}$} & \multirow[b]{2}{*}{$P$} & \multirow[b]{2}{*}{ OR } & \multirow[b]{2}{*}{$\mathrm{Cl}$} \\
\hline & & & $n$ & $\%$ & & $n$ & $\%$ & & $n$ & $\%$ & & $n$ & $\%$ & & $n$ & $\%$ & & $n$ & $\%$ & & & & \\
\hline \multirow[t]{2}{*}{ MMP-2_-1306C>T } & Allele & C & 124 & 78.5 & & & & $\mathrm{~T}$ & 34 & 21.5 & C & 257 & 76.0 & & & & $\mathrm{~T}$ & 81 & 24.0 & 0.362 & NS & & \\
\hline & Genotype & CC* & 50 & 63.3 & CT & 24 & 30.4 & $\pi$ & 5 & 6.3 & $\mathrm{CC}$ & 102 & 60.4 & $\mathrm{CT}$ & 53 & 31.4 & $\pi T$ & 14 & 8.3 & 0.361 & NS & 0.833 & $0.51-1.53$ \\
\hline \multirow{2}{*}{$M M P-7-|8| A>G$} & Allele & A & 105 & 66.5 & & & & G & 53 & 33.5 & A & 198 & 58.6 & & & & G & 140 & 41.4 & 2.810 & NS & & \\
\hline & Genotype & AA* & 34 & 43.0 & $A G$ & 37 & 46.8 & GG & 8 & 10.1 & AA & 46 & 27.2 & $A G$ & 106 & 62.7 & GG & 17 & 10.1 & 6.533 & $<0.04$ & 0.495 & $0.28-0.87$ \\
\hline \multirow{2}{*}{ MMP-7_-153C>T } & Allele & C & 149 & 94.3 & & & & $\mathrm{~T}$ & 9 & 5.7 & C & 320 & 94.7 & & & & $\mathrm{~T}$ & 18 & 5.3 & 0.029 & NS & & \\
\hline & Genotype & CC* & 70 & 88.6 & CT & 9 & 11.4 & $\pi T$ & - & 0 & $\mathrm{CC}$ & $15 \mid$ & 89.3 & $\mathrm{CT}$ & 18 & 10.7 & $\mathrm{TT}$ & - & 0 & 0.031 & NS & 1.079 & $0.46-2.52$ \\
\hline \multirow{2}{*}{ MMP-8_799C>T } & Allele & C & 84 & 53.2 & & & & $\mathrm{~T}$ & 74 & 46.8 & C & 191 & 56.5 & & & & $\mathrm{~T}$ & 147 & 43.5 & 0.487 & NS & & \\
\hline & Genotype & CC* & 19 & 24.1 & CT & 46 & 58.2 & $\pi$ & 14 & 17.7 & $\mathrm{CC}$ & 55 & 32.5 & CT & 81 & 48.0 & $T T$ & 33 & 19.5 & 2.509 & NS & 1.524 & $0.83-2.80$ \\
\hline \multirow{2}{*}{$M M P-8+17 C>G$} & Allele & C & 147 & 93.0 & & & & G & 11 & 7.0 & C & 309 & 91.4 & & & & G & 29 & 8.6 & 0.380 & NS & & \\
\hline & Genotype & $C C^{*}$ & 68 & 86.1 & CG & | | & 13.9 & GG & - & 0 & $\mathrm{CC}$ & $|4|$ & 83.4 & $C G$ & 27 & 16.0 & GG & 1 & 0.6 & 0.660 & NS & 0.781 & $0.37-1.66$ \\
\hline \multirow{2}{*}{ MMP-9_-1562C>T } & Allele & C & 137 & 86.7 & & & & $\mathrm{~T}$ & 21 & 13.3 & C & 286 & 84.6 & & & & $\mathrm{~T}$ & 52 & 15.4 & 0.376 & NS & & \\
\hline & Genotype & $C C^{*}$ & 59 & 74.7 & CT & 19 & 24.0 & Tा & I & 1.3 & $\mathrm{CC}$ & 120 & 71.0 & $\mathrm{CT}$ & 46 & 27.2 & $T T$ & 3 & 1.8 & 0.394 & NS & 0.830 & $0.45-1.52$ \\
\hline \multirow{3}{*}{ TIMP-I $372 C>T$} & Allele & C & 74 & 46.8 & & & & $\mathrm{~T}$ & 84 & 53.2 & C & 167 & 49.4 & & & & $\mathrm{~T}$ & |7| & 50.6 & 0.285 & NS & & \\
\hline & Genotype $q$ & $C C^{*}$ & 5 & 23.8 & CT & 10 & 47.6 & $\mathrm{TT}$ & 6 & 28.6 & $\mathrm{CC}$ & 24 & 22.4 & $\mathrm{CT}$ & 59 & 55.2 & $\mathrm{TT}$ & 24 & 22.4 & 0.481 & NS & 0.925 & $0.31-2.79$ \\
\hline & 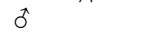 & $C^{*}$ & 27 & 46.6 & & & & $\mathrm{~T}$ & 31 & 53.4 & C & 30 & 48.4 & & & & $\mathrm{~T}$ & 32 & 51.6 & 0.040 & NS & 1.076 & $0.53-2.21$ \\
\hline \multirow{2}{*}{ TIMP-2 $303 \mathrm{C}>\mathrm{T}$} & Allele & C & 146 & 92.4 & & & & $\mathrm{~T}$ & 12 & 7.6 & $C$ & 301 & 89.0 & & & & $\mathrm{~T}$ & 37 & 11.0 & 1.359 & NS & & \\
\hline & Genotype & CC* & 68 & 86.1 & CT & 10 & 12.7 & Tा & I & 1.3 & $\mathrm{CC}$ & 133 & 78.7 & CT & 35 & 20.7 & $\mathrm{TT}$ & 1 & 0.6 & 2.588 & NS & 0.598 & $0.29-1.25$ \\
\hline \multirow[t]{2}{*}{ TIMP-2_4I $8 \mathrm{G}>\mathrm{C}$} & Allele & G & 157 & 99.4 & & & & $C$ & I & 0.6 & G & 337 & 99.7 & & & & $C$ & I & 0.3 & 0.305 & NS & & \\
\hline & Genotype & GG* & 78 & 98.7 & GC & I & 1.3 & $C C$ & - & 0 & GG & 168 & 99.4 & GC & I & 0.6 & $C C$ & - & 0 & 0.306 & NS & 2.154 & $0.13-34.9$ \\
\hline
\end{tabular}

$\mathrm{Cl}=$ confidence interval; $\mathrm{MMP}=$ matrix metalloproteinase; $\mathrm{NS}=$ not significant; $\mathrm{OR}=$ odds ratio; $\mathrm{PCR}=$ polymerase chain reaction; $\mathrm{SNP}=$ single-nucleotide polymorphism; TIMP = tissue inhibitor of metalloproteinase. The $\chi^{2}$ test was used to examine differences in the distributions of alleles and genotypes between patients and controls. OR and 95\% Cl were calculated by logistic regression using marked genotypes (*) as reference groups.

Table 3 Comparison of genotype distributions of the control subjects from this study $(n=169,107 q / 62 \hat{0})$ with the control groups from previously published studies

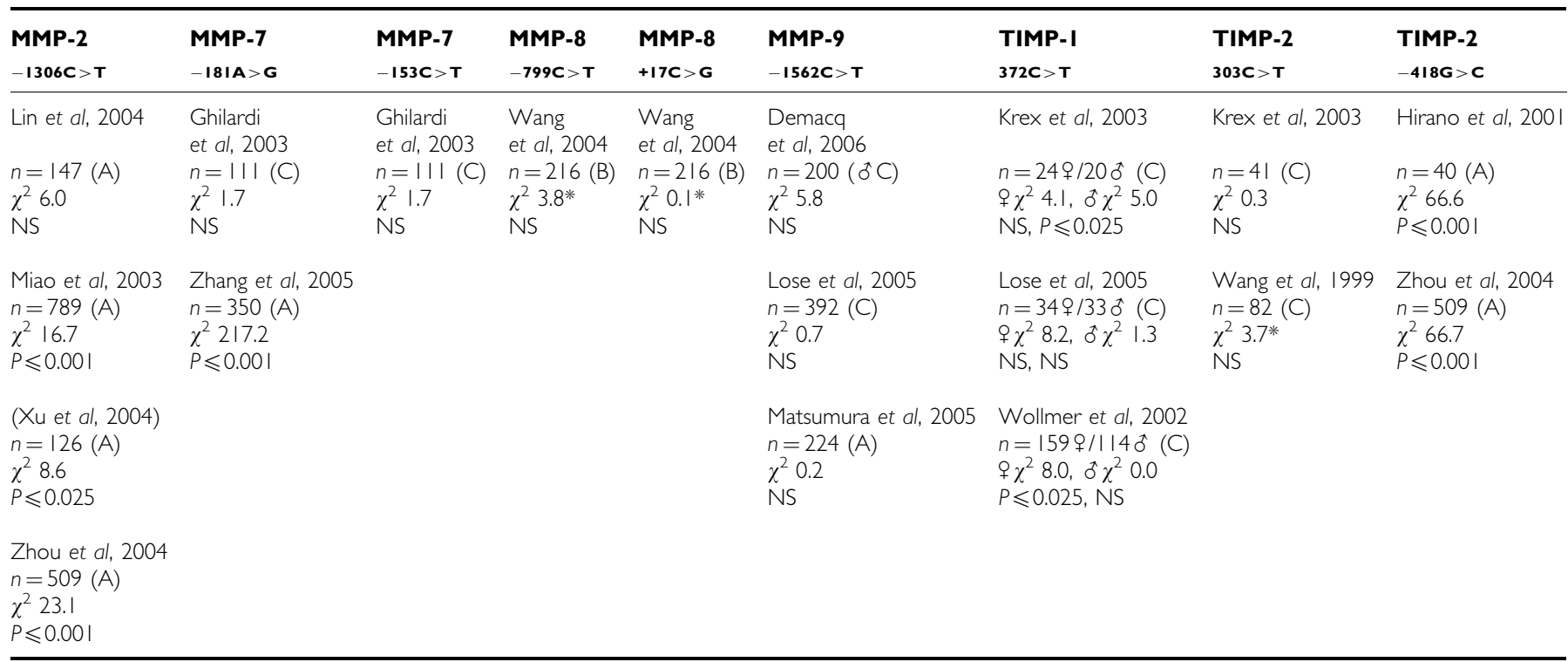

$\mathrm{MMP}=$ matrix metalloproteinase; NS = not significant; TIMP = tissue inhibitor of metalloproteinase. *Allele distribution. (A): Asiatic population, (B): Afro-American population, (C): Caucasian population. 
CC $70 \%$ and CT/TT $30 \%$ vs CC $48 \%$ and CT/TT $52 \%$; $\chi^{2} 3.5$, $P=0.06$ ), MMP-7 $-181 \mathrm{~A}>\mathrm{G}$ with the presence of $H p$ (negative $v s$ positive: AA $60 \%$ and AG/GG $40 \%$ vs AA $21 \%$ and AG/GG $79 \%$; $\chi^{2}$ $7.8, P=0.005)$ and TIMP $-2_{303 \mathrm{C}>\mathrm{T}}$ with the WHO classification (differentiated $v s$ not differentiated: CC $93 \%$ and CT/TT 7\% vs CC 72 and CT/TT 28\%; $\chi^{2} 5.9, P=0.03$ ).

The prognostic value for tumour-related survival of the respective SNPs was analysed using Cox proportional hazards analyses (Table 4 ). In the univariate analyses, TIMP-2 $303 \mathrm{C}>\mathrm{T}$ was significantly correlated with survival (Figure 1A), whereas MMP$7_{-181 \mathrm{~A}>\mathrm{G}}$ showed a trend (Figure 1B). From the clinicopathological parameters, only TNM classification and the presence of intestinal metaplasia were significantly associated with survival, whereas the localisation showed a trend. In a multivariate analysis against all the clinical parameters TIMP-2 $303 \mathrm{C}>\mathrm{T}$ kept its significance, indicating its potential value as an independent prognostic marker. A dendrogram showing a two-dimensional unsupervised hierarchical cluster analysis for all 79 patients using all the SNPs determined in this study is presented in Figure 2. Interestingly, the first-order cluster (I) separated the eight patients with mutations in both the survival-associated SNPs, that is, MMP-7 $-181 \mathrm{~A}>\mathrm{G}$ and TIMP-2 $303 \mathrm{C}>\mathrm{T}$, from the rest of the patients. Further analyses of this SNP combination revealed a stepwise and statistically significant poorer tumour-related survival for these mutations ( $0 \%$ ( 0 out of 11 patients) vs $32 \%$ (12 out of 37 patients) vs $52 \%$ (16 out of 31 patients); $\chi^{2} 9.7, P \leqslant 0.01$ ). Cox analyses

Table 4 Univariate and multivariate Cox proportional hazard analysis for gastric cancer patients testing SNPs for MMP and TIMP vs clinico-pathological parameters

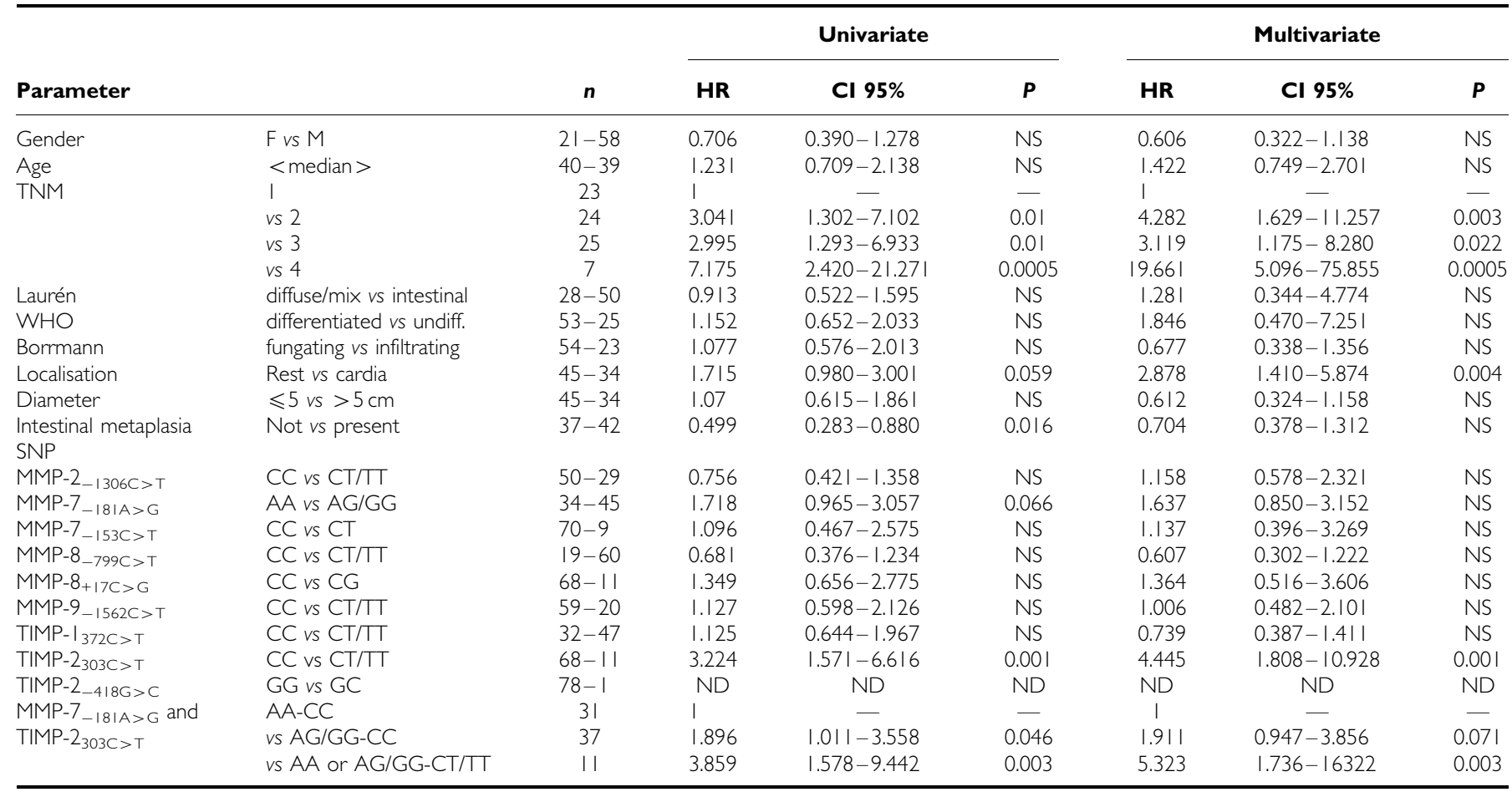

$\mathrm{Cl}=$ confidence interval; $\mathrm{F}=$ female; $\mathrm{HR}=$ hazard ratio; $\mathrm{M}=$ male; $\mathrm{MMP}=$ matrix metalloproteinase; $\mathrm{ND}=$ not defined; $\mathrm{NS}=$ not significant; $\mathrm{SNP}=$ single-nucleotide polymorphism; TIMP = tissue inhibitor of metalloproteinase; TNM = tumour node metastasis; $\mathrm{WHO}=$ World Health Organisation.
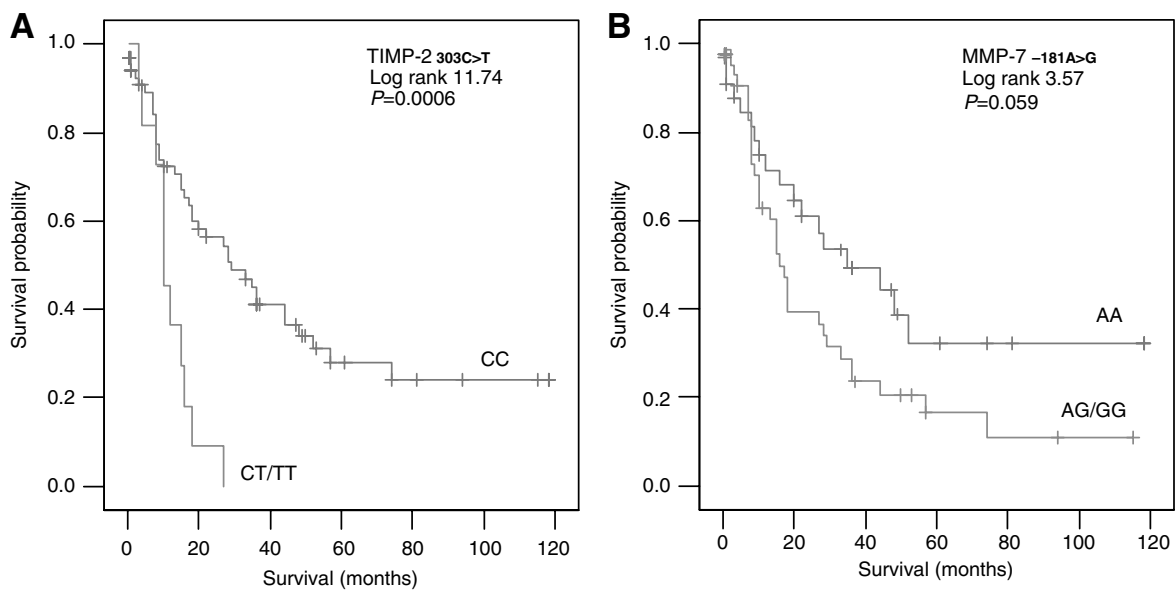

Figure I Survival curves using tumour-related death for 79 gastric cancer patients subdivided by the presence of a SNP in (A) the TIMP-2 gene $(303 C>T)$ and $(\mathbf{B})$ the MMP-7 gene $(-|8| A>G)$ 
confirmed this prognostic significance of this $\mathrm{MMP}_{-1} 7_{-181 \mathrm{~A}>\mathrm{G}}$ TIMP $-2_{303 \mathrm{C}>\mathrm{T}}$ combination, as indicated in Table 4 and illustrated in Figure 3.

The relation between the genotype distribution of the SNPs and the protein levels in normal and tumour tissue is shown in Table 5.

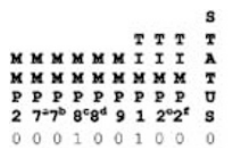

00001000100000

$\begin{array}{llllllllll}0 & 0 & 0 & 1 & 0 & 0 & 1 & 0 & 0 & 0 \\ 0 & 0 & 0 & 0 & 0 & 0 & 1 & 0 & 0 & 1\end{array}$

$\begin{array}{llllllllllllll}0 & 0 & 0 & 0 & 0 & 0 & 1 & 0 & 0\end{array}$

000110101000

$\begin{array}{lllllllllllll}0 & 0 & 0 & 1 & 1 & 0 & 1 & 0 & 0 \\ 0 & 0 & 0 & 2 & 0 & 0 & 1 & 0 & 0\end{array}$

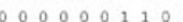

$\begin{array}{llllllllllllll}1 & 0 & 1 & 0 & 0 & 1 & 0 & 0 & 0\end{array}$

10000001000

1001000100

\begin{tabular}{llllllllll}
1 & 0 & 1 & 0 & 0 & 1 & 0 & 0 \\
\hline & 0 & 1 & 0 & 0 & 1 & 0 & 0
\end{tabular}

$\begin{array}{llllllllll}1 & 0 & 1 & 0 & 0 & 1 & 0 & 0 & 0\end{array}$

$\begin{array}{llllllllll}0 & 1 & 0 & 1 & 0 & 0 & 1 & 0 & 0 \\ 0 & 1 & 0 & 1 & 0 & 0 & 1 & 0 & 0\end{array}$

010000100

0100000100

011000000100

$\begin{array}{lllllllllll}1 & 0 & 0 & 0 & 0 & 1 & 0 & 0\end{array}$

0110000001009

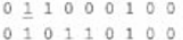

0100110100

$0 \begin{array}{llllllllllllllllll}0 & 1 & 0 & 2 & 1 & 0 & 1 & 0 & 0\end{array}$

$\begin{array}{lllllllll}1 & 1 & 2 & 0 & 0 & 1 & 0 & 0 & 0\end{array}$

010200100

00011011100

0001011000

0002201100

01001011100

010101100

0101011100

0110201100

10002011100

1001011000

1001001000

10001000

$\begin{array}{lllllllllll}1 & 0 & 0 & 1 & 0 & 0 & 1 & 0 & 0\end{array}$

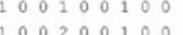

002001000

$\begin{array}{lllllllllll}0 & 0 & 2 & 1 & 0 & 1 & 0 & 0\end{array}$

1001000000

010100000

010000000000

$\begin{array}{lllllllll}1 & 0 & 1 & 0 & 0 & 0 & 0 & 0\end{array}$

1001000000

1001000000

10010000000

$\begin{array}{llllllllll}1 & 0 & 1 & 0 & 0 & 0 & 0 & 0 & 0\end{array}$

110000000

10021000000

11010000

1010101000

1000001000

10110010000

000011010000

000101000

1000101000

0010101000

0000010000

0002210000

00002100001

000100000

00001000000

000010000000

$\begin{array}{llllllll}0 & 0 & 0 & 0 & 0 & 0 & 0 & 0\end{array}$

00020000010

001000010

$\begin{array}{lllllll}\underline{1} & 1 & 0 & 0 & 0 & 0 & \underline{1}\end{array}$

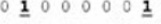

$\begin{array}{llllllll}0 & \underline{1} & 1 & 1 & 1 & 0 & 0 & \underline{1}\end{array}$

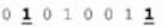

$0 \underline{1} 010001 \underline{1}$

$0 \underline{1} 100001 \underline{1}$

$0 \underline{1} 0000111$

$1 \underline{1} 01111 \underline{1} 0$

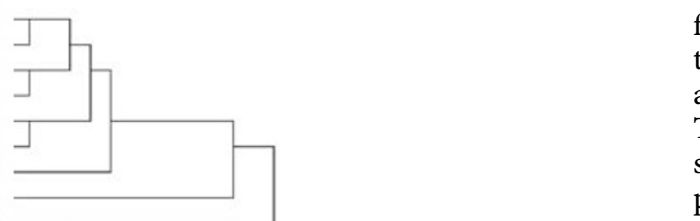

some gene polymorphisms of MMPs and TIMPs have been found to be related to disease susceptibility and changed gene transcription in vitro, we investigated whether gastric cancer is associated with SNPs of MMP-2, -7, -8 and -9 , or their inhibitors TIMP-1 and TIMP-2. The only SNP that was distributed significantly differently among gastric carcinoma patients compared to our control population was MMP-7 $-181 \mathrm{~A}>\mathrm{G}$, with more patients of the AA genotype than in controls. The latter was not expected from previous studies on gastrointestinal cancer (Ghilardi et al, 2003; Zhang et al, 2005) and is most likely caused by ethnic differences (Asiatic vs Caucasian; Table 3), disease localisation (gastric vs colon) and the relatively low number of patients included in the studies. In our study, the gastric cancer patients with the variant AG/GG genotype showed worse survival data than the AA patients (Table 4 and Figure 1B), although the difference did not fully reach statistical significance. The fact that tumours of the AG/GG patients did not contain higher MMP-7 antigen levels in our study suggests that the presence of SNP MMP$7_{-181 \mathrm{~A}>\mathrm{G}}$ alone is not directly translated into an enhanced tumour

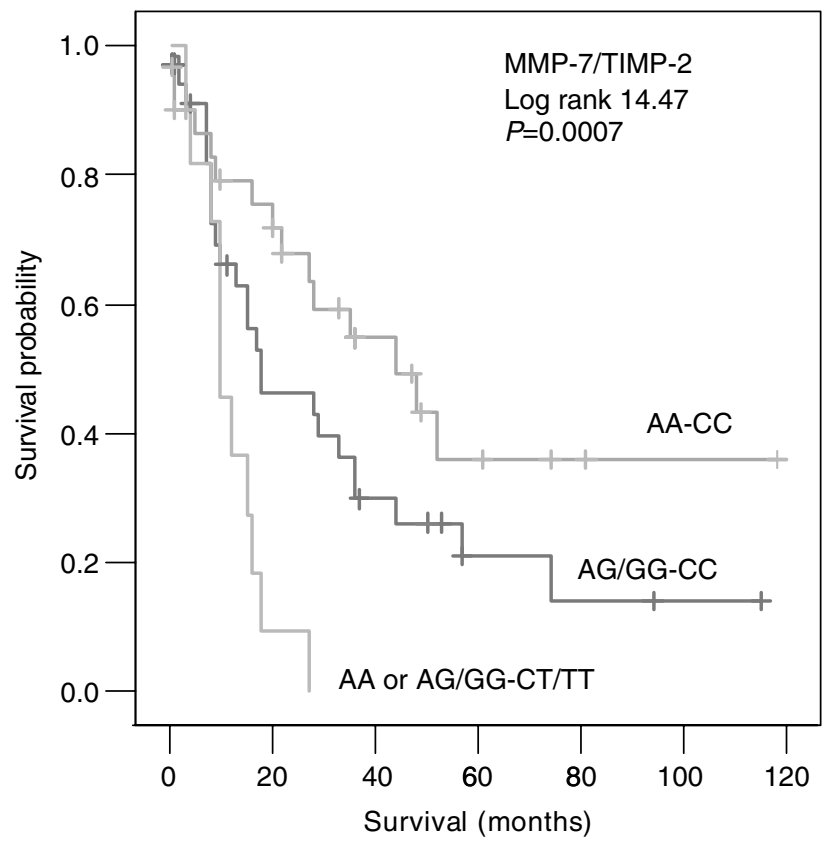

Figure 3 Survival curves using tumour-related death for 79 gastric cancer patients subdivided by the presence of combined polymorphisms in the MMP-7 gene $(-|8| A>G)$ and TIMP-2 gene $(303 C>T)$.

Figure 2 Dendrogram of a two-dimensional unsupervised hierarchical cluster analysis for 79 gastric cancer patients using SNPs of MMP$2_{-1306 \mathrm{C}>\mathrm{T}}, \quad$ MMP-7 $-181 \mathrm{~A}>\mathrm{C} \quad(\mathbf{A}), \quad-153 \mathrm{C}>\mathrm{G} \quad(\mathbf{B}), \quad \mathrm{MMP}-8_{-799 \mathrm{C}>\mathrm{T}}(\mathbf{C})$ $+17 \mathrm{C}>\mathrm{G}(\mathbf{D}), \mathrm{MMP}_{-1}{ }_{-1562 \mathrm{C}>\mathrm{T}}, \mathrm{TIMP}_{3} \mathrm{I}_{372 \mathrm{C}>\mathrm{T}}$, and TIMP-2 $303 \mathrm{C}>\mathrm{T}(\mathbf{E})$, $-418 \mathrm{G}>\mathrm{C}(\mathbf{F})$. For all the SNPs, 0 stands for the reference genotype and I for the combined other genotypes as described in Table 2. Because of the distribution, for MMP-8_799C $>\mathrm{T}(\mathbf{C})$ a three-group subdivision was used: $0=C C, I=C T, 2=T$. Status: $0=$ alive or not tumour-related death, $\mathrm{I}=$ tumour-related death. 


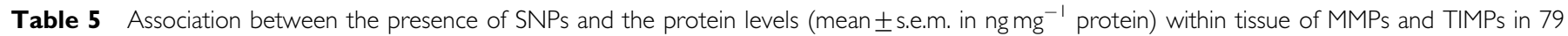
gastric carcinoma patients

Protein level

\begin{tabular}{|c|c|c|c|c|c|c|c|}
\hline \multirow{2}{*}{\multicolumn{2}{|c|}{$\begin{array}{l}\text { SNP } \\
\text { Located in promoter }\end{array}$}} & \multicolumn{6}{|c|}{ focen } \\
\hline & & \multicolumn{2}{|c|}{ Normal mucosa } & \multirow{2}{*}{$\frac{\text { P-value }}{\text { NS }}$} & \multicolumn{2}{|c|}{ Tumour } & \multirow{2}{*}{$\frac{\text { P-value }}{0.03}$} \\
\hline MMP-2_1306C >T & CC vs CT/TT & $5.0 \pm 0.5$ & $4.5 \pm 0.7$ & & $18.2 \pm 2.4$ & $14.9 \pm 3.8$ & \\
\hline MMP-7_-153C>T & $C C$ vs $\mathrm{CT}^{\mathrm{a}}$ & $2.2 \pm 0.6$ & $0.7 \pm 0.0$ & 0.019 & $47.1 \pm 14.1$ & $46.1 \pm 16.4$ & NS \\
\hline MMP-7_-18|A>G & $A A$ vs $A G / G G$ & $1.3 \pm 0.4$ & $2.1 \pm 0.6$ & NS & $52.1 \pm 22.3$ & $43.4 \pm 15.0$ & NS \\
\hline MMP-8_799C>T & CC vs CT/TT & $|39 \pm 3|$ & $83 \pm 12$ & 0.044 & $305 \pm 67$ & $326 \pm 60$ & NS \\
\hline MMP $-8+17 C>G$ & CC vs CG & $98 \pm 19$ & $95 \pm 15$ & NS & $302 \pm 51$ & $440 \pm 140$ & NS \\
\hline MMP-9-1562C>T & CC vs CT/TT & $9.7 \pm 1.1$ & $7.0 \pm 1.5$ & NS & $26.9 \pm 2.8$ & $19.4 \pm 3.3$ & NS \\
\hline TIMP-2_-4I8G >C & GG vs GC & $6.0 \pm 0.3$ & $5.1^{-}$ & NS & $6.3 \pm 0.4$ & 5.2 & NS \\
\hline \multicolumn{8}{|l|}{ Located in exon } \\
\hline TIMP-I $372 C>T$ & CC vs CT/TT & $8.7 \pm 1.6$ & $7.7 \pm 0.7$ & NS & $18.8 \pm 2.6$ & $15.7 \pm 1.4$ & NS \\
\hline TIMP-2 $303 \mathrm{C}>\mathrm{T}$ & CC vs CT/TT & $6.0 \pm 0.3$ & $5.6 \pm 0.6$ & NS & $6.0 \pm 0.4$ & $7.5 \pm 1.6$ & NS \\
\hline
\end{tabular}

$\mathrm{MMP}=$ matrix metalloproteinase; $\mathrm{NS}=$ not significant; $\mathrm{SNP}=$ single-nucleotide polymorphism; $\mathrm{TIMP}=$ tissue inhibitor of metalloproteinase. ${ }^{a} n=3 .{ }^{b} n=1$.

MMP-7 antigen expression or activity. However, considering the previously shown localised presence of MMP-7 at the invasive front of tumours, immunohistochemical or in vitro studies might further elucidate this functional relationship. The other striking correlation of MMP-7 $-181 \mathrm{~A}>\mathrm{G}$ in this study is with the presence of $\mathrm{Hp}$. Gastric cancer patients with the AG/GG genotype were significantly more often $\mathrm{Hp}$-positive, which might indicate an enhanced susceptibility for this bacterium. The presence of $H p$ is associated with the development of gastric cancer and stimulation of MMP-7 production by $\mathrm{Hp}$ in human gastric epithelial cells has previously been suggested as a possible mechanism predisposing towards gastric neoplasia (Wroblewski et al, 2003; Chen et al, 2004).

Tissue inhibitor of metalloproteinase-2 is involved in the regulation of MMP-2 activity (Howard et al, 1991; Wang et al, 2000). In addition, TIMP-2 has been shown to promote cell growth (Hayakawa et al, 1994). Enhanced amounts of TIMP-2 protein are found to be associated with prostate cancer malignancies (Ross et al, 2003), but for colon and gastric cancer the correlation with clinico-pathological parameters has not been established (Ring et al, 1997; Joo et al, 2000). In our study, the CT/TT variant of TIMP $-2_{303 \mathrm{C}>\mathrm{T}}$ was observed more frequently in undifferentiated gastric carcinomas (WHO classification) and it was associated with worse tumour-related survival of gastric cancer patients. Tissue inhibitor of metalloproteinase- $2_{303 \mathrm{C}>\mathrm{T}}$ is located in exon 3 with no effect on the final amino-acid sequence of the protein (S101S) and no effect on the total TIMP-2 expression between gastric normal and tumour tissue (Table 5). Therefore, the TIMP-2 $203 \mathrm{C}>\mathrm{T}$ SNP behaves as a disease susceptibility gene polymorphism by a so far undefined mechanism. The other SNP for TIMP-2 in this study $(-418 \mathrm{G}>\mathrm{C})$, localised in the promoter of the gene, has been described to abolish the Sp1-binding site and therefore may downregulate TIMP-2 gene expression (Hirano et al, 2001). A

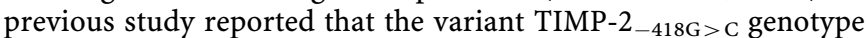
(GC or CC) was indeed associated with a moderately reduced risk of breast cancer in a Chinese population (Zhou et al, 2004). Because our group of Caucasian gastric cancer patients contained only one patient with the variant genotype (GC), we could not determine an association with tumour staging, patient survival or antigen expression.

The first-order cluster in a two-dimensional unsupervised hierarchical cluster analysis including all SNPs clearly separated the patients with mutations in both the survival-associated SNPs, that is, MMP-7 $-181 \mathrm{~A}>\mathrm{G}$ and TIMP-2 $2_{303 \mathrm{C}>\mathrm{T}}$ from the rest of the patients. Cox analysis confirmed this SNP combination as a prognostic parameter for gastric cancer. Although results of cluster analysis of SNPs in gastric cancer have not been published before, hierarchical cluster analysis of patterns of chromosomal aberra- tions in gastric cancer patients identified patients with worse prognosis as well (Weiss et al, 2003), confirming the validity of such an approach.

The $(-1306 \mathrm{C}>\mathrm{T}) \mathrm{SNP}$ in the promoter of the MMP-2 gene has also been found to diminish promoter activity by abolishing the Spl-binding site (Price et al, 2001). Consequently, the variant genotypes (CT/TT) are expected to produce less MMP-2 antigen, which consequently might be associated with decreased cancer risk or better survival of the patients (Sier et al, 1996). Although we did not find a significant difference in distribution of MMP- $2_{-1306 \mathrm{C}>\mathrm{T}}$ between gastric cancer patients and controls, the tumours from patients with the CT/TT genotypes contained significantly less MMP-2 antigen than the CC genotype (Table 5). This relation was expected, but as far as we know, never shown before. The fact that the MMP- $2_{-1306 \mathrm{C}>\mathrm{T}}$ status on its own was not correlated with survival might be explained by the complicated activation mechanism of MMP-2 in which several other proteins are involved. Changes in MMP-2 antigen levels are therefore not directly correlated with MMP-2 activity levels. The fact that we did not find a relation with survival in our group of patients supports the study of Miao et al (2003), describing that the CC genotype was not associated with higher risk of metastasis at the time of diagnosis. A weak but significant difference in genotype distribution of MMP- $2_{-1306 \mathrm{C}>\mathrm{T}}$ and gastric carcinomas, classified according to the Borrmann classification, was observed with the highest percentage of the CC genotype in type $1 / 2$ (fungating) preceding infiltrating tumours (type 3/4). This underscores the role of MMP-2 in breaking down the extracellular matrix in early gastric cancer which has been suggested before (Miao et al, 2003).

The genotype distribution of MMP- $9_{-1562 \mathrm{C}>\mathrm{T}}$ in our group of healthy controls was not different from other publications. We did not find differences in genotype distribution for MMP-9 $-1562 \mathrm{C}>\mathrm{T}$ between gastric cancer patients and controls either, which is in agreement with the study of Matsumura et al (2005) in Japanese patients. However, that study showed significant associations of the CT/TT genotype with depth of invasion, lymphatic invasion and TNM classification. In our study, MMP-9 ${ }_{-1562 \mathrm{C}>\mathrm{T}}$ was not correlated with clinico-pathological parameters or survival. Moreover, MMP-9 antigen levels in normal as well as tumour tissue of gastric cancer patients with the MMP- $9_{-1562 \mathrm{C}>\mathrm{T}}$ genotype were not enhanced, as was recently also found in plasma of healthy subjects (Demacq et al, 2006). Our results indicate that the presence of the $\mathrm{T}$ allele variant in the MMP-9 promoter $(-1562 \mathrm{C}>\mathrm{T})$ is not associated with clinical outcome in our Caucasian group of gastric cancer patients.

Neutrophils secrete both gelatinase B (MMP-9) and neutrophil collagenase (MMP-8) after stimulation. Matrix metalloproteinase-8 
expression levels correlated with tumour stage and poor prognosis in ovarian cancer (Stadlmann et al, 2003). Levels of MMP-8 and -9 correlated significantly with each other and with TIMP-1 levels, but were not related to tumour size or prognosis in human breast cancer (Duffy et al, 1995). Nothing has been published thus far about SNPs for MMP-8 and cancer, but three MMP-8 promoter haplotypes (MMP-8 $-799 \mathrm{C}>\mathrm{T}, \mathrm{MMP}-8_{+17 \mathrm{C}>\mathrm{G}}$ and MMP-8 $-381 \mathrm{~A}>\mathrm{G}$ ) have been found to be associated with preterm rupture of membranes in delivery, indicating a functional role on MMP-8 expression (Wang et al, 2004). Because MMP- $8+17 \mathrm{C}>\mathrm{G}$ and MMP$8_{-381 \mathrm{~A}>\mathrm{G}}$ were found to be in complete linkage disequilibrium, we decided to study the distribution of MMP- $8_{-799 \mathrm{C}>\mathrm{T}}$, MMP$8+17 \mathrm{C}>\mathrm{G}$ in our group of gastric cancer patients. However, we did not find any relation of both SNPs with protein levels, clinico-pathological parameters, or survival in this study.

TIMP-1 is a ubiquitous glycoprotein capable of inhibiting all activated collagenases (Gomez et al, 1997). Tissue inhibitor of metalloproteinases were previously found not to be correlated with tumour stage, histological type, lymph node status or survival in human gastric cancer (Murray et al, 1998). We did not find any relation of TIMP-1 $1_{372 \mathrm{C}>\mathrm{T}}$ with gastric carcinoma, protein level or survival of the patients.

Taken together, our data indicate that MMP and TIMP gene polymorphisms contribute to gastric carcinogenesis. Determination of these gene polymorphisms, especially MMP-7 $-181 \mathrm{~A}>\mathrm{G}$ and TIMP $-2_{303 \mathrm{C}>\mathrm{T}}$ both as single parameter and in combination as a cluster, might be helpful to identify gastric cancer patients with a poor clinical outcome and in need of (neo)-adjuvant treatment aiming at better outcome.

\section{ACKNOWLEDGEMENTS}

We are grateful to Marij Mieremet-Ooms and Wim van Duijn for their outstanding technical assistance and Drs Patrick van der Veek and Ad Masclee for the collection of blood from healthy volunteers.

\section{REFERENCES}

Chen JQ, Zhan WH, He YL, Peng JS, Wang JP, Cai SR, Ma JP (2004) Expression of heparanase gene, CD44v6, MMP-7 and nm23 protein and their relationship with the invasion and metastasis of gastric carcinomas. World J Gastroenterol 10: 776-782

Demacq C, de Souza AP, Machado AA, Gerlach RF, Tanus-Santos JE (2006) Genetic polymorphism of matrix metalloproteinase (MMP)-9 does not affect plasma MMP-9 activity in healthy subjects. Clin Chim Acta 365: $183-187$

Duffy MJ, Blaser J, Duggan C, McDermott E, O'Higgins N, Fennelly JJ, Tschesche H (1995) Assay of matrix metalloproteases types 8 and 9 by ELISA in human breast cancer. Br J Cancer 71: $1025-1028$

Egeblad M, Werb Z (2002) New functions for the matrix metalloproteinases in cancer progression. Nat Rev Cancer 2: $161-174$

Ghilardi G, Biondi ML, Erario M, Guagnellini E, Scorza R (2003) Colorectal carcinoma susceptibility and metastases are associated with matrix metalloproteinase-7 promoter polymorphisms. Clin Chem 49: 1940 - 1942

Gomez DE, Alonso DF, Yoshiji H, Thorgeirsson UP (1997) Tissue inhibitors of metalloproteinases: structure, regulation and biological functions. Eur J Cell Biol 74: $111-122$

Harendza S, Lovett DH, Panzer U, Lukacs Z, Kuhnl P, Stahl RA (2003) Linked common polymorphisms in the gelatinase A promoter are associated with diminished transcriptional response to estrogen and genetic fitness. J Biol Chem 278: 20490-20499

Hayakawa T, Yamashita K, Ohuchi E, Shinagawa A (1994) Cell growthpromoting activity of tissue inhibitor of metalloproteinases-2 (TIMP-2). J Cell Sci 107(Part 9): 2373-2379

Hermanek P, Sobin LH (1992) UICC: TNM classification of malignant tumours. Berlin: Springer Verlag

Hirano K, Sakamoto T, Uchida Y, Morishima Y, Masuyama K, Ishii Y, Nomura A, Ohtsuka M, Sekizawa K (2001) Tissue inhibitor of metalloproteinases-2 gene polymorphisms in chronic obstructive pulmonary disease. Eur Respir J 18: 748-752

Honda M, Mori M, Ueo H, Sugimachi K, Akiyoshi T (1996) Matrix metalloproteinase-7 expression in gastric carcinoma. Gut 39: $444-448$

Howard EW, Bullen EC, Banda MJ (1991) Preferential inhibition of 72- and $92-\mathrm{kDa}$ gelatinases by tissue inhibitor of metalloproteinases-2. J Biol Chem 266: $13070-13075$

Janssen AM, Van Duijn W, Kubben FJ, Griffioen G, Lamers CB, van Krieken JH, van de Velde CJ, Verspaget HW (2002) Prognostic significance of metallothionein in human gastrointestinal cancer. Clin Cancer Res 8: $1889-1896$

Joo YE, Seo KS, Kim HS, Rew JS, Park CS, Kim SJ (2000) Expression of tissue inhibitors of metalloproteinases (TIMPs) in gastric cancer. Dig Dis Sci 45: $114-121$

Jormsjö S, Whatling C, Walter DH, Zeiher AM, Hamsten A, Eriksson P (2001) Allele-specific regulation of matrix metalloproteinase-7 promoter activity is associated with coronary artery luminal dimensions among hypercholesterolemic patients. Arterioscler Thromb Vasc Biol 21: $1834-1839$
Kohn EC, Liotta LA (1995) Molecular insights into cancer invasion: strategies for prevention and intervention. Cancer Res 55: 1856- 1862

Krex D, Rohl H, Konig IR, Ziegler A, Schackert HK, Schackert G (2003) Tissue inhibitor of metalloproteinases-1, -2 , and -3 polymorphisms in a white population with intracranial aneurysms. Stroke 34: 2817-2821

Kubben FJ, Sier CF, Van Duijn W, Griffioen G, Hanemaaijer R, van de Velde CJ, van Krieken JH, Lamers CB, Verspaget HW (2006) Matrix metalloproteinase-2 is a consistent prognostic factor in gastric cancer. Br J Cancer 94: 1035-1040

Lin SC, Lo SS, Liu CJ, Chung MY, Huang JW, Chang KW (2004) Functional genotype in matrix metalloproteinases-2 promoter is a risk factor for oral carcinogenesis. J Oral Pathol Med 33: 405-409

Lose F, Thompson PJ, Duffy D, Stewart GA, Kedda MA (2005) A novel tissue inhibitor of metalloproteinase-1 (TIMP-1) polymorphism associated with asthma in Australian women. Thorax 60: 623-628

Lowry OH, Rosebrough NJ, Farr AL, Randall RJ (1951) Protein measurement with the Folin phenol reagent. J Biol Chem 193: 265-275

Matsumura S, Oue N, Nakayama H, Kitadai Y, Yoshida K, Yamaguchi Y, Imai K, Nakachi K, Matsusaki K, Chayama K, Yasui W (2005) A single nucleotide polymorphism in the MMP-9 promoter affects tumor progression and invasive phenotype of gastric cancer. J Cancer Res Clin Oncol 131: $19-25$

Miao X, Yu C, Tan W, Xiong P, Liang G, Lu W, Lin D (2003) A functional polymorphism in the matrix metalloproteinase-2 gene promoter $(-1306 \mathrm{C} / \mathrm{T})$ is associated with risk of development but not metastasis of gastric cardia adenocarcinoma. Cancer Res 63: 3987-3990

Miller SA, Dykes DD, Polesky HF (1988) A simple salting out procedure for extracting DNA from human nucleated cells. Nucleic Acids Res 16: 1215

Mori M, Mimori K, Shiraishi T, Fujie T, Baba K, Kusumoto H, Haraguchi M, Ueo H, Akiyoshi T (1997) Analysis of MT1-MMP and MMP2 expression in human gastric cancers. Int J Cancer 74: 316-321

Murray GI, Duncan ME, Arbuckle E, Melvin WT, Fothergill JE (1998) Matrix metalloproteinases and their inhibitors in gastric cancer. Gut 43: $791-797$

Nomura H, Sato H, Seiki M, Mai M, Okada Y (1995) Expression of membrane-type matrix metalloproteinase in human gastric carcinomas. Cancer Res 55: $3263-3266$

Price SJ, Greaves DR, Watkins H (2001) Identification of novel, functional genetic variants in the human matrix metalloproteinase- 2 gene: role of Sp1 in allele-specific transcriptional regulation. J Biol Chem 276: $7549-7558$

Ring P, Johansson K, Hoyhtya M, Rubin K, Lindmark G (1997) Expression of tissue inhibitor of metalloproteinases TIMP-2 in human colorectal cancer - a predictor of tumour stage. Br J Cancer 76: 805-811

Ross JS, Kaur P, Sheehan CE, Fisher HA, Kaufman Jr RA, Kallakury BV (2003) Prognostic significance of matrix metalloproteinase 2 and tissue inhibitor of metalloproteinase 2 expression in prostate cancer. Mod Pathol 16: $198-205$ 
Sier CF, Kubben FJ, Ganesh S, Heerding MM, Griffioen G, Hanemaaijer R, van Krieken JH, Lamers CB, Verspaget HW (1996) Tissue levels of matrix metalloproteinases MMP-2 and MMP-9 are related to the overall survival of patients with gastric carcinoma. Br J Cancer 74: 413-417

Stadlmann S, Pollheimer J, Moser PL, Raggi A, Amberger A, Margreiter R, Offner FA, Mikuz G, Dirnhofer S, Moch H (2003) Cytokine-regulated expression of collagenase-2 (MMP-8) is involved in the progression of ovarian cancer. Eur J Cancer 39: 2499-2505

van der Veek PP, van den BM, de Kroon YE, Verspaget HW, Masclee AA (2005) Role of tumor necrosis factor-alpha and interleukin-10 gene polymorphisms in irritable bowel syndrome. Am J Gastroenterol 100: $2510-2516$

Wang H, Parry S, Macones G, Sammel MD, Ferrand PE, Kuivaniemi H, Tromp G, Halder I, Shriver MD, Romero R, Strauss III JF (2004) Functionally significant SNP MMP8 promoter haplotypes and preterm premature rupture of membranes (PPROM). Hum Mol Genet 13: $2659-2669$

Wang X, Tromp G, Cole CW, Verloes A, Sakalihasan N, Yoon S, Kuivaniemi $\mathrm{H}$ (1999) Analysis of coding sequences for tissue inhibitor of metalloproteinases 1 (TIMP1) and 2 (TIMP2) in patients with aneurysms. Matrix Biol 18: 121 - 124

Wang Z, Juttermann R, Soloway PD (2000) TIMP-2 is required for efficient activation of proMMP-2 in vivo. J Biol Chem 275: $26411-26415$

Weiss MM, Kuipers EJ, Postma C, Snijders AM, Siccama I, Pinkel D, Westerga J, Meuwissen SG, Albertson DG, Meijer GA (2003) Genomic profiling of gastric cancer predicts lymph node status and survival. Oncogene 22: $1872-1879$

Wollmer MA, Papassotiropoulos A, Streffer JR, Grimaldi LM, Kapaki E, Salani G, Paraskevas GP, Maddalena A, de Quervain D, Bieber C,
Umbricht D, Lemke U, Bosshardt S, Degonda N, Henke K, Hegi T, Jung HH, Pasch T, Hock C, Nitsch RM (2002) Genetic polymorphisms and cerebrospinal fluid levels of tissue inhibitor of metalloproteinases 1 in sporadic Alzheimer's disease. Psychiatry Genet 12: 155-160

Wroblewski LE, Noble PJ, Pagliocca A, Pritchard DM, Hart CA, Campbell F, Dodson AR, Dockray GJ, Varro A (2003) Stimulation of MMP-7 (matrilysin) by Helicobacter pylori in human gastric epithelial cells: role in epithelial cell migration. J Cell Sci 116: 3017-3026

Xu E, Lai M, Lv B, Xing X, Huang Q, Xia X (2004) A single nucleotide polymorphism in the matrix metalloproteinase-2 promoter is associated with colorectal cancer. Biochem Biophys Res Commun 324: 999- 1003

Ye S, Dhillon S, Ke X, Collins AR, Day IN (2001) An efficient procedure for genotyping single nucleotide polymorphisms. Nucleic Acids Res 29: E88

Zhang B, Ye S, Herrmann SM, Eriksson P, de Maat M, Evans A, Arveiler D, Luc G, Cambien F, Hamsten A, Watkins H, Henney AM (1999) Functional polymorphism in the regulatory region of gelatinase B gene in relation to severity of coronary atherosclerosis. Circulation 99: $1788-1794$

Zhang J, Jin X, Fang S, Wang R, Li Y, Wang N, Guo W, Wang Y, Wen D, Wei L, Dong Z, Kuang G (2005) The functional polymorphism in the matrix metalloproteinase-7 promoter increases susceptibility to esophageal squamous cell carcinoma, gastric cardiac adenocarcinoma and non-small cell lung carcinoma. Carcinogenesis 26: 1748-1753

Zhou Y, Yu C, Miao X, Tan W, Liang G, Xiong P, Sun T, Lin D (2004) Substantial reduction in risk of breast cancer associated with genetic polymorphisms in the promoters of the matrix metalloproteinase- 2 and tissue inhibitor of metalloproteinase-2 genes. Carcinogenesis 25: $399-404$ 